Gulawentah: Jurnal Studi Sosial

ISSN 2528-6293 (Print); ISSN 2528-6871 (Online)

Vol. 3, No. 2, Desember 2018, Hal 90-99

Tersedia Online: http://e-journal.unipma.ac.id/index.php/gulawentah

\title{
Kirab Pusaka Sunan Kumbul di Kecamatan Sawoo Kabupaten Ponorogo (Studi Nilai Budaya dan Potensinya Sebagai Sumber Pembelajaran IPS SMP)
}

\author{
Y. Yuliani \\ SMPN 2 Kecamatan Sawoo Kabupaten Ponorogo, Indonesia \\ Email: yuli.ponorogo2015@gmail.com
}

\begin{abstract}
Abstrak
Penelitian ini bertujuan untuk mendiskripsikan dan menganalisis ceremonial dan nilainilai budaya upacara Kirab Pusaka Sunan Kumbul di Kecamatan Sawoo Kabupaten Ponorogo serta mendiskripsikan dan menganalisis potensinya sebagai sumber pembelajaran IPS SMP. Penelitian ini menggunakan pendekatan kualitatif deskriptif. Penelitian dilaksanakan di Kecamatan Sawoo mulai bulan Oktober 2017 sampai dengan bulan Agustus 2018. Informan ditentukan dengan purposive sampling. Validasi data digunakan teknik triangulasi sumber, sedangkan analisis datanya menggunakan model interaktif. Hasil penelitian menggambarkan bahwa Kirab Pusaka Sunan Kumpul merupakan upacara tradisional untuk mengiring pusaka Sunan Kumpul yang berupa Tombak Kyai Dora Manggala. Iringan-iringan dipimpin Camat Sawoo dan tokoh-tokoh pemerintahan kecamatan dan masyarakat. Sunan Kumpul tidak lain adalah Brojonatan yang dipercaya sebagai senopati dari Paku Buwono II Surakarta yang berjasa dalam kehidupan masyarakat Sawoo. Kirab pusaka ini menggunakan piranti/perlengkapan dan ceremonial yang mengandung nilai-nilai budaya, diantaranya; religius, gotong-royong atau kerjasama, rela berkorban, disiplin, saling hormat-menghormati, saling menghargai, patriotisme, patuh, bertanggung jawab, dan toleransi. Nilai-nilai tersebut memiliki potensi sebagai sumber pembelajaran IPS SMP kelas VII semester 1 yaitu pada KD 3.1 Memahami konsep ruang dan interaksi antar ruang di Indonesia serta pengaruhnya terhadap kehidupan manusia dalam aspek ekonomi, sosial, budaya, dan pendidikan.
\end{abstract}

Kata kunci: kirab pusaka; nilai budaya; sumber pembelajaran; IPS

\section{A Carnival of Sunan Kumbul's Heirloom in Sawoo District, Ponorogo Regency (A Study of Cultural Values and Their Potentials as Learning Sources of Social Science for Junior High School)}

\begin{abstract}
This study aims at describing and analysing cultural values on the carnival of Sunan Kumbul's heirloom and their potentials as learning sources of Social Science for junior high school. The study used descriptive qualitative research design. It was conducted in Sawoo district, Ponorogo regency starting from October 2017 to August 2018. The informants was selected through purposive sampling. Data were validated by using source triangulation and they were analysed by using interactive model. The results show that the carnival of Sunan Kumbul's heirlooms is a traditional ceremony showing off the heirloom namely Kyai Dora Manggala spear. The carnival is led by the head of Sawoo district and followed by all district officers and people in the surrounding. Sunan Kumbul is Brojonatan believed as a commander for the king Paku Buwono II Surakarta, who was meritorious for Sawoo community life. The carnival uses tools and has rituals covering some cultural values such as religious, cooperative, willing to sacrifice, discipline, respecting others, appreciating others, patriotic, obedient, responsible, and tolerated. The values potentially become learning sources of Social Science (IPS) for the seventh grade
\end{abstract}

DOI: $10.25273 /$ gulawentah.v3i2.3462

Copyright (C) 2018 Universitas PGRI Madiun

All rights reserved. 
students. The sources are for semester one, with basic competence (KD) 3.1: understanding space concept and the space interaction in Indonesia, the influence on the human's life in the economic, social, cultural, and educational aspects as well.

Keywords: carnival; cultural values; learning sources; Social Science (IPS)

\section{Pendahuluan}

Kebudayaan adalah hasil pemikiran, cipta dan karya manusia yang berkembang di masyarakat. Pikiran dan perbuatan yang dilakukan oleh manusia secara terus menerus pada akhirnya menjadi sebuah tradisi. Tradisi merupakan proses situasi kemasyarakatan yang didalamnya terdapat unsur-unsur dari warisan kebudayaan dan dipindahkan dari generasi ke generasi. Salah satu bagian dari budaya adalah tradisi. Tradisi dilaksanakan dalam sebuah komunitas dalam rangka memenuhi kebutuhannya, minimal kebutuhan rasa aman dan akulturasi diri. Simanjuntak (2016: 94) menyatakan bahwa esensi tertinggi dari melaksanakan upacara tradisi adalah dalam rangka kelepasan, artinya dalam rangka mencari perlindungan dan bantuan untuk menemukan ketentraman, kesejahteraan dan keabadian.

Istilah kebudayaan berdasarkan Kusumohamidjojo (dalam Uhi, 2016: 3) berasal dari kata dasar budaya yang berarti : 1) Pikiran, akal budi, hasil budaya; 2) Adat istiadat, menyelidiki bahasa dan budaya; 3) Sesuatu mengenai kebudayaan yang berkembang (beradab, maju); 4) Sesuatu yang sudah menjadi kebiasaan, yang sudah sukar diubah. Istilah kebudayaan disebut sebagai: 1) Hasil kegiatan dan penciptaan batin (akal budi) manusia, seperti kepercayaan, kesenian, dan adat istiadat; 2) Keseluruhan pengetahuan manusia sebagai makluk sosial yang digunakan untuk memahami lingkungan serta pengalamannya, dan menjadi pedoman tingkah lakunya. Kebudayaan merupakan kekayaan yang sangat bernilai tinggi, karena merupakan ciri khas suatu daerah dan menjadi lambang kepribadian suatu bangsa atau daerah dimana kebudayaan tersebut berada. Maka menjaga, memelihara dan melestarikan budaya merupakan kewajiban dari setiap individu atau masyarakat supaya kebudayaan tersebut tidak hilang tetapi dapat terus hidup di masyarakat.

Pada masa sekarang sebagian generasi muda bangsa Indonesia lebih memilih kebudayaan asing yang mereka anggap lebih tinggi nilainya, lebih menarik dan praktis. Sehingga banyak kebudayaan lokal yang mulai luntur akibat tidak ada generasi penerus yang mewarisinya. Perlunya menumbuhkan kesadaran akan pentingnya menjaga nilai-nilai budaya lokal menjadi kewajiban seluruh masyarakat. Peran serta masyarakat untuk terus berusaha mewarisi merupakan kekuatan supaya budaya ini tetap ada. Kebudayaan lokal merupakan faktor utama berdirinya kebudayaan nasional oleh karena itu menjadi tanggung jawab generasi muda untuk dapat mewarisi budaya lokal sehingga secara tidak langsung sudah ikut menjaga budaya nasional bangsa ini.

Begitu juga masyarakat Ponorogo yang memiliki berbagai macam budaya dan tradisi yang berbeda-beda di setiap daerahnya. Sepantasnya kita masyarakat Ponorogo bersikap bangga atas segala nilai seni dan kekayaan budaya yang dimiliki. Budaya dan seni yang ada di Ponorogo merupakan warisan leluhur yang penuh dengan nilai sejarah panjang hingga mampu menciptakan sebuah identitas khas bagi masyarakat Ponorogo. Festifal Reog, Kirap Pusaka dan Larung Risalah Doa merupakan bagian dari beberapa agenda kegiatan rutin yang dilaksanakan satu tahun sekali dalam rangka memperingati ulang tahun Kabupaten Ponorogo, memperingati hari kemerdekaan RI dan juga menyambut datangnya tahun baru Hijriah yaitu 1 Muharam atau akrab dikenal dimasyarakat dengan istilah 1 Suro.

Disalah satu Kecamatan di Kabupaten Ponorogo memiliki tradisi ritual yang hampir sama meskipun tujuan dan waktu pelaksanaannya berbeda yaitu "Kirab Pusaka Sunan Kumbul" yang dilaksanakan disetiap bulan Agustus, dilaksanakan untuk memperingati hari kemerdekaan Republik Indonesia. Kegiatan ini berada di Kecamatan Sawoo yang terletak di wilayah timur Kabupaten Ponorogo berbatasan dengan Kabupaten Trenggalek yang berjarak kurang lebih $25 \mathrm{~km}$ dari kota Ponororgo dengan daerahnya yang sebagian besar pegunungan sehingga sebagian besar masyarakat masih bersifat tradisional. Masih banyak masyarakat yang sangat percaya terhadap mistis, sehingga 
masyarakat di sini secara rutin melaksanakan ritual ini dan meyakini bahwa Sunan Kumbul adalah orang yang babad di daerah Sawoo. Di tempat ini terdapat petilasan yang mereka yakini tempat pertama kali Sunan Kumbul datang, sehingga sebagai bentuk penghormatan dan untuk mengingat sejarah babad Sawoo dilaksanakanlah Kirab Pusaka Sunan Kumbul.

Pada masa pemerintah kecamatan Sawoo dipmpin oleh putra asli daerah Sawoo maka adat istiadat kirab pusaka ini dimunculkan dan di angkat menjadi event rutin Kecamatan Sawoo sampai sekarang .Tepatnya pada tahun 2008 yang pada waktu itu dipimpin Camat Bambang Hariyanto yang masih keturunan dari Eyang Dipoyudo yang diberi amanah untuk menjaga pusaka leluhur Surakarta (Tombak Kyai Dora Manggolo), pusaka tombak Kyai Dora Manggolo merupakan pusaka dari keraton Surakarta yang diberikan oleh Sunan Kumbul (Paku Buwono II) kepada abdi setia yang menemani Paku Buwono II selama di Sawoo yaitu Eyang Dipoyudo, yang kemudian menjadi cikal bakal babad Desa Sawoo Kecamatan Sawoo.

Kirab Pusaka Sunan Kumbul sampai sekarang rutin dilakukan oleh seluruh masyarakat Sawoo setiap bulan Agustus. Namun tidak sedikit masyarakat yang belum tahu makna nilai budaya apa yang terkandung dalam kegiatan Kirap Pusaka Sunan Kumbul di Kecamatan Sawoo Kabupaten Ponorogo serta Potensinya untuk dapat digunakan sebagai sumber pembelajaran IPS SMP. Hal ini bila terjadi terus menerus akan berakibat pada budaya yang kehilangan maknanya sehingga suatu saat nanti budaya tersebut akan hilang dari masyarakat. Pada hal kesenian tradisional di Indonesia pada umumnya mengandung nilai luhur dan berpotensi sebagai sumber pembelajaran IPS. Oleh karena itu penelitian ini menarik dan perlu untuk dilaksanakan.

Menurut Suprayogo (2001:41) ritual atau ritus adalah serangkaian kata, tindakan pemeluk agama dengan menggunakan benda-benda, peralatan dan perlengkapan tertentu, ditempat tertentu dan memakai pakaian tertentu pula. Sedangkan adat mengandung makna sebagai kebiasaan yang bersifat magis religius dari suatu masyarakat yang meliputi nilai-nilai budaya dan aturan-aturan yang saling berkaitan, kemudian menjadi suatu sistim tradisi (Hendra,2013:16). Pelaksanaan ritual pada umumnya ditandai dengan adanya unsur waktu, tempat pelaksanaan, alat dan benda-benda dalam upacara serta orang-orang yang menjalankan upacara. Unsur-unsur tersebut merupakan kewajiban sehingga setiap melaksanakan upacara keempat unsur tersebut harus disertakan.

Turner (dalam Winangun,1990) menggolongkan ritus menjadi 2 yaitu ritus krisis hidup dan ritus gangguan. Ritus krisis hidup diadakan untuk mengiringi krisis hidup yang dialami manusia seperti kelahiran, pubertas, perkawinan dan kematian. Sedangkan ritus gangguan adalah ritus yang diadakan untuk menolak gangguan seperti menolak nasib sial, menolak gangguan dari makluk gaib dan lain sebagainya. Ritual adat sebagai rangkain tindakan atau perbuatan yang terikat pada aturan tertentu berdasarkan adat istiadat yang meliputi: (a) Bersesaji yaitu perbuatan untuk menyajikan makan, benda-benda, dan sebagainya yang ditujukan kepada Tuhan, Dewa, ruh nenek moyang atau makluk halus, (b) Berdoa yaitu permohonan yang diiringi dengan gerak dan sikap tubuh tertentu sebagai sikap dan gerak menghormati serta merendah diri pada leluhur, terhadap Tuhan ataupun Dewata. (c) Makan bersama atau kenduri, (d) Berprosesi yaitu suatu perbuatan berpawai dengan membawa lambang-lambang tertentu supaya mendatangkan berkah atau menolak bala, (e) Berpuasa yaitu menahan nafsu dalam waktu tertentu, (f) Bersemedi yaitu menyepi guna memusatkan perhatian kepada maksudnya kepada hal-hal yang suci (Koentjaraningrat, 2009).

Rangkaian kegiatan ini merupakan unsur pokok didalam melaksanakan upacara tradisional namun tidak semua kegiatan secara terperinci dilakukan pada saat pelaksanaannya. Piranti ritual upacara adat berupa berbagai uba rampe yang diperlukan selama ritual berlangsung. Uba rampe dalam ritual upacar adat bisa berupa binatang sebagai korban, dupa, sesajen, ambengan untuk selamatan dan lain sebagainya. Ubo rampe ritual adat biasanya tidak sama antara ritual adat satu dengan yang lainnya.

Masyarakat jawa masih kental dengan hal-hal mistik salah satu diantaranya Kirab Puasaka. Kirab Pusaka disebut sebagai upacara adat karena dilakukan secara tetap, pada waktu tertentu, dan dilangsungkan secara turun temurun. Upacar Kirab pusaka bertujuan memohon keselamatan kepada Tuhan Yang Maha Esa. Ritual Kirab Pusaka yang selalu dilaksanakan masyarakat kebudayaan Jawa khususnya di Keraton Kasunanan Surakarta Hadiningrat. Ritual tersebut dilaksanakan berdasarkan keyakinan masyarakat Jawa yaitu Kejawen. Kirab biasanya dengan penyucian benda-benda pusaka keraton kemudian mengaraknya keliling keraton. Pusaka tersebut dianggap memiliki daya magis 
yang dipercaya mengandung daya kesaktian. Pusaka-pusaka yang dikirab tersebut adalah peninggalan dari kerajaan-kerajaan masa lampau sehingga selain mempunyai daya magis juga mempunyai daya historis yang sangat kuat. Pusaka yang dianggap mengandung kekuatan magis itu diharapkan akan memancarkan keselamatan dan kesejahteraan bagi keraton Surakarta dan negara Indonesia pada umumnya. Pusaka disini bukan dianggap sebagai sumber kekuatan melainkan hanya sebagai sarana dan media karunia Tuhan yang ditujukan kepada manusia. Semua pusaka yang dikirab biasanya diberi sebutan "Kanjeng Kyai" karena kesaktiannya mampu memancarkan keselamatan dan kesejahteraan.

Upacara Adat kirab Pusaka termasuk salah satu hasil dari ekspresi hasrat manusia yang dilatar belakangi tradisi yang ada di masyarakat sehingga di kemas sedemikian rupa untuk bisa diterima oleh seluruh lapisan masyarakat setempat tanpa menghilangkan tradisi aslinya. Koentjaraningrat (2009) menyampaikan bahwa wujud kebudayaan adalah kompleksitas dari berbagai ide-ide, norma, gagasan, serta peraturan dimana kompleks aktifitas dan tindakan tersebut berpola dari manusia itu sendiri dan pada umumnya berwujud berbagai benda -benda hasil ciptaan manusia.

Nilai merupakan suatu hal yang dianggap baik atau buruk bagi kehidupan. Nilai merupakan sesuatu yang abstrak, namun hal tersebut menjadi pedoman bagi kehidupan masyarakat. Nilai budaya menurut Uhi (dalam Hanif,2016) merupakan konsepsi umum yang terorganisir dan dapat mempengaruhi perilaku manusia dalam hubungannya dengan lingkungan alam dan lingkungan sosial. Sistim nilai budaya dengan sendirinya, dapat dijadikan pedoman serta prinsip-prinsip umum dalam bertindak dan bertingkah laku sehingga nilai selalu berkaitan dengan wujud perilaku pada manusia. Koentjaraningrat (2009) juga menyampaikan bahwa nilai budaya terdiri dari konsepsikonsepsi yang hidup dalam alam fikiran sebagian besar warga masyarakat mengenai hal - hal yang mereka anggap amat mulia, sehingga dapat berfungsi sebagai pedoman yang memberi arah kehidupan para warga masyarakat.

Alwi (dalam Wiyana,2013:129) menjelaskan sumber pembelajaran dapat diartikan sebagai asal bahan yang dipikir, dibicarakan, dibahas, dan diujikan dalam kegiatan belajar peserta didik. Dalam implementasi kurikulum 2013 sifat pembelajaran haruslah konstekstual dan buku teks tidaklah dijadikan sebagai satu-satunya sumber materi pembelajaran. Pembelajaran konstekstual menurut Rahyubi (2012: 233) adalah konsep belajar yang membantu guru mengaitkan antara materi yang diajarkan dengan situasi dunia nyata peserta didik dan mendorong peserta didik membuat hubungan antara pengetahuan yang dimilikinya dengan penerapannya dalam kehidupan mereka sehari-hari dengan melibatkan enam komponen utama pembelajaran konstruktivisme, bertanya, menemukan, masyarakat pembelajar, pemodelan dan penilaian.

Sumber belajar merupakan hal yang paling penting dalam proses belajar mengajar. Tanpa adanya sumber belajar seseorang tidak dapat mengumpulkan informasi atau pengetahuan yang akan ia pelajari sebagai pengetahuan baru yang bermanfaat bagi dirinya sendiri maupun orang lain. Sumber belajar sangat dibutuhkan untuk menggali semua informasi yang kita perlukan dalam memahami materi yang sedang dipelajari. Begitu pula saat kita akan belajar tentang materi IPS. Menurut Komalasari (2010: 108) sumber pelajaran adalah segala sesuatu atau daya yang dapat dimanfaatkan oleh guru, baik secara terpisah maupun dalam bentuk gabungan, untuk kepentingan belajar mengajar dengan tujuan meningkatkan efektivitas dan efisiensi tujuan pembelajaran. Edger Dale (dalam Musfiqon, 2012: 129) juga menjelaskan sumber belajar adalah pengalaman-pengalaman yang pada dasarnya sangat luas, yakni seluas kehidupan yang mencakup segala sesuatu yang dapat dialami dan dapat menimbulkan peristiwa belajar.

\section{Metode Penelitian}

Penelitian dilaksanakan di Pura Sanggha Bhuana Lanud Iswahyudi Maospati Magetan. Penelitian dilaksanakan selama 6 bulan yaitu mulai bulan Februari 2018 sampai Juli 2018 dengan menggunakan pendekatan kualitatif. Pendekatan yang digunakan ini lebih bersifat deskripsi dan kategorisasi berdasarkan kondisi kancah penelitian. Penelitian ini menggunakan konsep naturalistik yaitu apa yang terjadi di kancah penelitian menjadi ukuran data yang paling bisa diterima. Penelitian 
dilakukan dengan pendekatan kualitatif. Informan ditentuk dengan purposive sampling yang terdiri dari para sesepuh masyarakat Sawoo, juru kunci dan keturunan Eyang Dipoyudo. Penelitian dilaksanakan mulai bulan Oktober 2017 sampai dengan bulan Agustus 2018. Teknik pengumpulan data yang digunakan wawancara, observasi dan dokumentasi.

Teknik pengumpulan data dengan wawancara mendalam, observasi, dan pencatatan dokumen. Data divalidasi dengan teknik triangulasi sumber. Sedangkan analisis datanya menggunakan analisis kualitatif model interaktif Miles dan Huberman (1992). Analisa ini dilakukan bersamaan dengan proses pengumpulan data. Pengumpulan data dibuat reduksi data dan sajian datanya. Apabila pengumpulan data sudah selesai, peneliti bergerak diantara tiga komponen yaitu reduksi data, sajian data, dan penarikan kesimpulan. Dari rangkaian kegiatan tersebut, kemudian kesimpulan yang dibuat dirasa kurang mantap, maka peneliti kembali ke proses pengumpulan data.

\section{Hasil dan Pembasan}

Kecamatan Sawoo merupakan salah satu kecamatan yang berada di kabupaten Ponorogo terletak disebelah timur yang berbatasan langsung dengan Kabupaten Trenggalek kurang lebih 30 $\mathrm{Km}$ dari kota ponorogo berada di ketinggian 103 meter sampai dengan 980 meter diatas permukaan laut dengan luas wilayah 124,702 Km2 yang secara administratif terbagi dalam 14 desa yaitu : Desa Tumpuk, Desa Pangkal, Desa Tumpakpelem, Desa Tempuran, Desa Sriti, Desa Temon, Desa Sawoo, Desa Prayungan, Desa Tugurejo, Desa Grogol, Desa Ketro, Desa Kori, Desa Bondrang, Desa Ngideng.

Kondisi geografis yang sebagian besar adalah pegunungan yang meliputi 8 desa yang ada di kecamatan Sawoo, menyebabkan mayoritas penduduk bermata pencaharian sebagai petani dan buruh tani, dari luas wilayah 124,702 KM2 yang merupakan lahan pertanian seluas 5.698.66 KM2.. Sedangkan jumlah penduduk di Kecamatan Sawoo sampai dengan akhir tahun 2017 adalah sejumlah 66.191 jiwa yang terdiri dari penduduk laki - laki sejumlah 33.002 jiwa dan penduduk perempuan sejumlah 33.189 Jiwa.

Ceremonial Kirab Pusaka Sunan Kumbul di Kecamatan Sawoo Kabupaten Ponorogo dilatarbelakangi adanya tradisi dan kepercayaan masyarakat Sawoo terhadap adanya petilasan Sunan Kumbul. Masyarakat berpandangan bahwa Sunan Kumpul tidak lain adalah Brojonatan yang dipercaya sebagai senopati dari Paku Buwono II Surakarta. Masyarakat percaya bahwa pusaka Sunan Kumpul bertuah dan bisa mendatangkan keselamatan. Untuk itu masyarakat melakukan upacara.

Kirab Pusaka Sunan Kumbul ini dilakukan oleh Pemerintahan Kecamatan Sawoo untuk melestarikan budaya yang sudah ada disana dengan mengangkat kegiatan Kirab Pusaka ini pada peringatan hari kemerdekaan Republik lindonesia. Upaya pemerintah kecamatan Sawoo ini sejalan dengan Undang-Undang Nomor 5 Tahun 2017 tentang Pemajuan Kebudayaan dimana pemerintah berkewajiban untuk melakukan pemajuan kebudayaan yang merupakan upaya meningkatkan ketahanan budaya dan kontribusi budaya Indonesia ditengah peradaban dunia melalui pelindungan, pengembangan, pemanfaatan, dan pembinaan kebudayaan yang dilakukan dengan cara inventarisasi, pengamanan, pemeliharaan, penyelamatan dan publikasi. Dimana disini pemerintah Kecamatan Sawoo sudah melakukan pelindungan, pengembangan dan pemanfaatan objek pemajuan kebudayaan menguatkan idiologi, politik, ekonomi, sosial, budaya, pertahanan dan keamanan dalam mewujudkan tujuan nasional. Kirab ini dilaksanakan di Kecamatan Sawoo pada setiap bulan Agustus setelah tanggal 17 sebagai puncak peringatan HUT RI. 


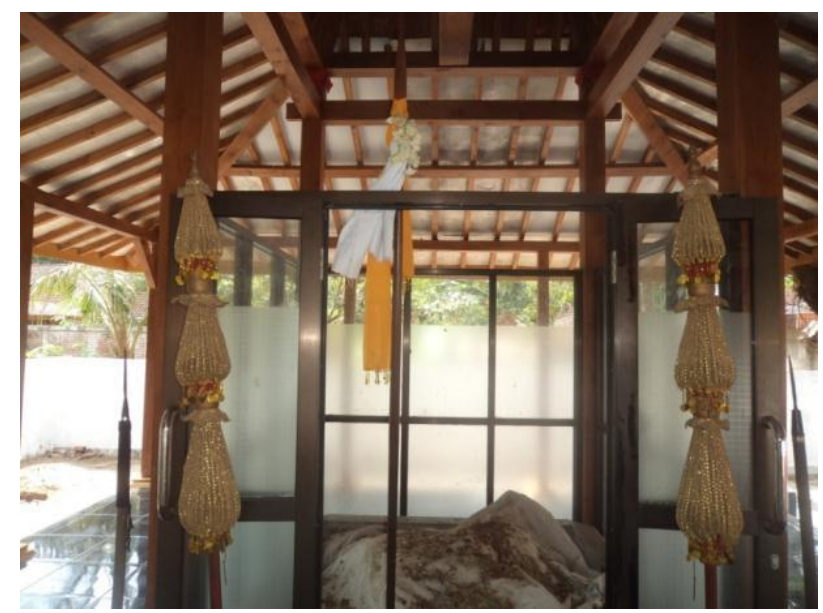

Gambar 1.Tombak Kyai Dora Manggala

Tujuan dilaksanakan kirab antara lain; (1) Untuk mengenalkan tempat, benda dan sejarah Sawoo kepada seluruh masyarakat Sawoo khususnya dan bangsa Indonesia umumnya agar mereka tahu tentang sejarah lokal. Sehingga akan terus menjaga benda-benda peninggalan dan juga tempat yang memiliki nilai sejarah tidak mengalami kerusakan sehingga sampai kapanpun akan terjaga kelestariannya, (2) Sebagai media pewarisan budaya, (3) Menumbuhkan rasa patriotisme, (4) Untuk meningkatkan pendapatan ekonomi masyarakat Sawoo khususnya dan bangsa Indonesia pada umumnya dari sektor pariwisata.

Selain pewarisan budaya tersebut di atas, Kirap Pusaka Sunan Kumpul juga dijadikan sebagai edukasi kepada masyarakat bagaimana menempatkan diri antara peguasa dan bawahanya, bagaimana bersikap ketika sesorang mendapatkan amanah dan kepercayaan, bagaimana kita harus selalu ingat dan berdoa kepada Allah SWT ketika dalam kondisi apapun.dan juga menanamkan semangat perjuangan kepada generasi muda untuk bisa menjunjung tinggi budaya yang ada serta tidak lupa terhadap sejarah, apa yang terjadi sekarang ini tidak lepas dari sejarah masa lalu bangsa kita salah satunya disini juga sejarah tentang babad atau sejarah Sawoo.

Piranti yang terdapat pada waktu pra pelaksanaan yaitu merupakan piranti yang ada pada waktu selamatan atau nyadran dimana dalam acara selamatan itu terdapat:sego brok, Panggang ayam, buceng kuat, sego golong, sego punar, gulo gimbal gulo grising, macam-macam jenang, apem, kemenyan, anglo dan arang.

Piranti yang terdapat pada waktu prosesi pelaksanaan Kirab Pusaka Sunan Kumbul meliputi Tombak Kyai Dora Manggala beserta landeannya, kembang setaman, kembang wangi, kemenyan anglo dan arang, kain mori putih, kain putih kuning, rangakaian bunga melati, Tebu ireng, kambil gading dan pisang Rojo satu tandan beserta pohonnya. 


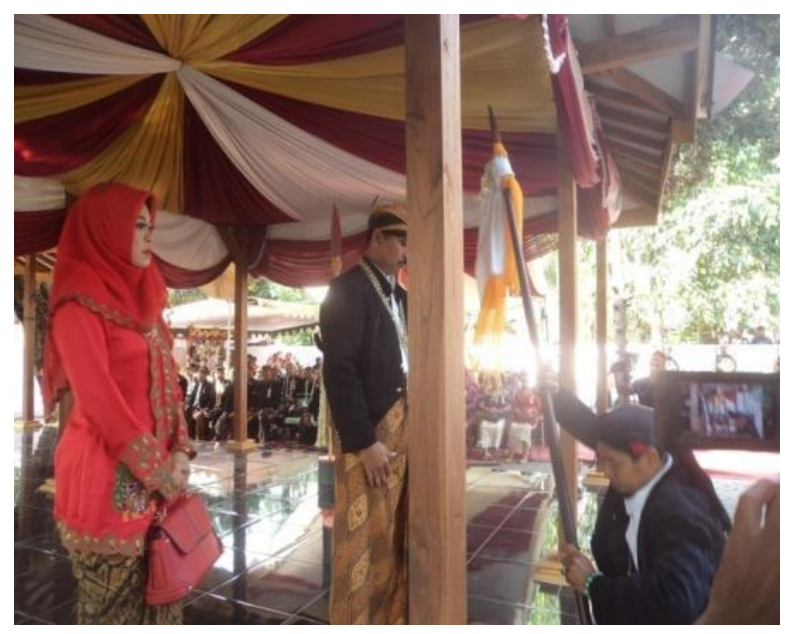

Gambar 2. Penyerahan Pusaka

Prosesi kirab sebenarnya sudah dilakukan sejak malam hari menjelang kirab yaitu ketika dilakukan selamatan (wilujengan) di petilasan sunan kumbul kirim doa kepada leluhur desa Sawoo dan mengharap kepada Allah SWT supaya seluruh masyarakat Sawoo diberikan perlindungan dan keselamatan dari segala macam bahaya yang mengancam. Hal ini sesuai dengan pendapat Daliman (2012:49) selamatan bertujuan untuk keselamatan dan ketentraman yang intinya adalah memanjatkan doa kepada Tuhan Yang Maha Esa. Setelah melakukan upacara ini maka masyarakat akan merasa aman dan nyaman karena sudah melaksanakan apa yang biasanya dilakukan oleh generasi-generasi sebelumnya.

Pada pagi hari sebelum prosesi kirab Tombak Kyai Dora Manggala dipinjam dari kediaman bapak Soekarnin (yang menyimpan tombak Kyai Dora Manggala) untuk di bawa ke petilasan Sunan Kumbul, sesampainya di petilasan diterima oleh Juru kunci petilasan kemudian diletakkan disisi petilasan dan juga dilengkapi kembang setaman. Juru kunci membakar kemenyan dan menabur bunga dipetilasan. Setelah Camat Sawoo yang sekaligus memimpin prosesi kirab tiba di Petilasan maka prosesi kirab di petilasan Sunan Kumbul dimulai, prosesi tersebut diawali: Pembasuhan kaki Camat yang kemudian Camat sarimbit dipersilahkan duduk ditempat yang sudah disediakan, rombongan kepala desa / kepala unit dinas instansi sarimbit memasuki tempat yang sudah disediakan, ditampilkan tari Bedayan, penyerahan pusaka Tombak Kyai Dora manggolo dari juru kunci kepada Camat, Pembacaan doa dengan tembang Pangkur, Pemberangkatan Kirab Dora Manggolo, sampai dipemakaman Brajanatan berhenti sebentar Camat sarimbit melakukan tabur bunga dan perjalanan dilanjutkan sampai pendopo kecamatan.

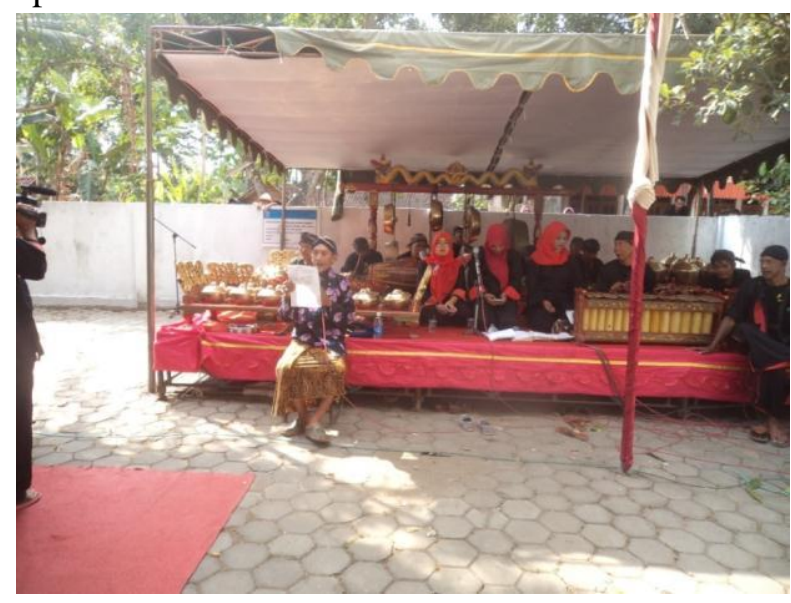

Gambar 3. Pembacaan Doa Kirab Pusaka 
Prosesi di pendopo Kecamatan sebagai berikut Senopati, prajurit dan rombongan pembawa pusaka memasuki halaman kecamatan, Camat sarimbit masuk dikalungi bunga, peserta kirab yang lain mengikuti menempati tempat yang sudah di tentukan, tampilan tari gambyong, penyerahan pusaka Tombak Kyai Dora Manggala kembali kepada Camat, pembacaan asal muasal Sawoo, sambutan Camat, Doa dan penutup.

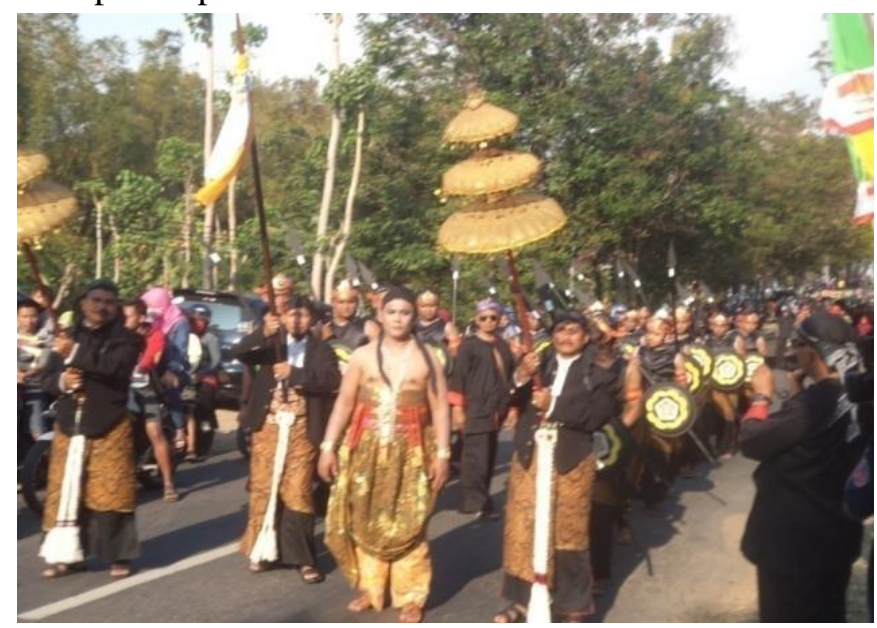

Gambar 4.Barisan Kirab Pusaka Sunan Kumpul

Nilai-nilai budaya yang terdapat dalam kirab Pusaka Sunan Kumbul yaitu:

a. Nilai religius dimana terdapat adat selamatan atau nyadran dan juga pembakaran kemenyan yang dilakukan oleh kuncen disertai dengan doa-doa sebagai bentuk hubungan antara manusia dengan penciptanya.

b. Gotong royong dan kerjasama yang terlihat jelas selama prosesi ini berlangsung, karena dalam kirab ini membutuhkan kerjasama antara semua peserta kirab. Dengan prosesi yang begitu besar tentunya juga membutuhkan pengorbanan waktu, materi dan juga tenaga. Hal-hal seperti ini tentunya sangat penting untuk diketahui oleh seluruh masyarakat terutama generasi muda, sehingga nilai budaya gotong royong ini akan terus terjaga kelestariannya.

c. Rela berkorban, nilai budaya ini dapat kita lihat dari apa yang dilakukan oleh seluruh petugas kirab dimana mereka harus dengan ikhlas berkorban waktu, tenaga dan juga materi. Mereka harus berjalan kaki dari petilasan Sunan Kumbul menuju Aula Kecamatan Sawoo maka jelas prosesi ini membutuhkan pengorbanan energi dan waktu dari seluruh peserta Kirab.

d. Disiplin, ini dapat terlihat selama prosesi berlangsung prajurit tetap berdiri tegak melakukan tugasnya meskipun harus berdiri lama dengan posisi sama, petugas pembawa pusaka harus melakukan jalan jongkok ketika harus menerima tombak Kyai Dora Manggala untuk dikirab dan arak-arakan berjalan sesuai urutan yang sudah ditentukan, ini merupakan beberapa bentuk nyata disiplin yang dilakukan oleh petugas juga peserta kirab ini.

e. Saling hormat menghormati yang ini dapat terlihat ketika prosesi di petilasan maupun yang ada di aula Kecamatan Sawoo ketika petugas kirab melakukan sesembahan sebagai bentuk hormat ketika mereka mau menerima dan menyerahkan kembaki pusaka setelah prosesi kirab, termasuk juga penyiraman kaki Camat sekalian oleh kuncen merupakan bentuk menghormati anatara kawula dengan penguasa. Tidak ada pikiran dengan melakukan prosesi ini akan merendahkan harga diri kuncen dimata masyarakat.

f. Saling menghargai hal ini dapat kita lihat ketika rapat untuk mengangkat kirab pusaka ini menjadi event kecamatan tentunya banyak sekali pendapat antara setuju dan tidak setuju namun dapat terlaksana dengan baik tentunya karena mereka memiliki rasa menghargai satu dengan

Gulawentah: Jurnal Studi Sosial Vol. 3, No. 2, Desember 2018, hal 90-99 
yang lain. juga terlihat jelas ketika pembagian tugas sebagai petugas kirab dimana sebagian besar diambilkan dari peserta didik disemua sekolah SMP dan SMK yang berada di kecamatan Sawoo.

g. Patriotisme, nilai budaya ini sesuai ketika event ini dilakukan bersamaan dengan peringatan HUT RI. Menumbuhkan semangat patriotisme dengan belajar mencintai kebudayaannya sendiri serta melestarikannya dan menjadikan para pahlawan sebagai suri tauladan, karena bentuk rasa patriotisme dimasa lalu dan masa sekarang wujudnya berbeda.

h. Patuh, bentuk nilai sosial patuh dapat kita lihat pada apa yang sudah dilakukan oleh keturunan Eyang Dipoyudo untuk menjaga petilasan dan juga Tombak Kyai Dora Manggala agar tetap terjaga keberadaannya meskipun ini mereka lakukan tanpa adanya imbalan apapun.

i. Bertanggungjawab, dapat terlihat ketika prosesi berlangsung semua melaksanakan tugas masing-masing sehingga prosesi dapat berjalan lancar, dan juga tanggungjawab yang diemban oleh keturunan Eyang Dipoyudo ini menujukan jika mereka memiliki rasa tanggungjawab terhadap tugas yang mereka emban.

j. Toleransi begitu terasa manakala prosesi kirab ini merupakan perpaduan akulturasi budaya Islam dan Hindu yang ternyata masih tetap dilaksanakan dan diterima oleh masyarakat sekarang, mereka sudah dapat membedakan antara agama dan budaya. Adanya sesaji merupakan bentuk budaya asli sebelum agama-agama seperti sekarang ini masuk kemudian dalam kegiatan doa kita sudah menggunakan cara islam termasuk dalam penyembelihan binatang yang digunakan untuk selamatan.

Nilai-nilai budaya Kirab Pusaka Sunan Kumbul ini di atas berpotensi untuk dijadikan sebagai sumber pembelajaran IPS SMP minimal SMP di Kecamatan Sawoo. Hal tersebut sejalan dengan pendapat Alwi (dalam Wiyani 2013:129) bahwa sumber pembelajaran dapat diartikan sebagai asal bahan yang dipikir, dibicarakan, dibahas, dan diujikan dalam kegiatan belajar peserta didik. Selain itu juga dalam seiring dengan Kurikulum 2013.

Dalam implementasi kurikulum 2013 sifat pembelajaran haruslah konstekstual dan buku teks tidaklah dijadikan sebagai satu-satunya sumber materi pembelajaran. Pembelajaran konstekstual menurut Rahyubi (2012: 233) adalah konsep belajar yang membantu guru mengaitkan antara materi yang diajarkan dengan situasi dunia nyata peserta didik dan mendorong peserta didik membuat hubungan antara pengetahuan yang dimilikinya dengan penerapannya dalam kehidupan mereka sehari-hari dengan melibatkan enam komponen utama pembelajaran konstruktivisme, bertanya, menemukan, masyarakat pembelajar, pemodelan dan penilaian.

Prosesi upacara Kirab Pusaka Sunan Kumpul dan nilai-nilai budaya yang terkandung di dalam dapat dijadikan sebagai sumber pembelajaran IPS SMP kelas VII semester 1. Dalam Kurikulum 2013 di kelas tersebut disampaikan materi pokoknya yaitu Dinamika Kependudukan Indonesia KD 3.1 Memahami konsep ruang (lokasi, distribusi, potensi,iklim,bentuk muka bumi, geologis, flora dan fauna) dan interaksi antarruang di Indonesia serta pengaruhnya terhadap kehidupan manusia dalam aspek ekonomi, sosial, budaya, dan pendidikan.

\section{Simpulan}

Dari hasil penelitian dan pembahasan di atas maka dapat disimpulkan bahwa Kirab Pusaka Sunan Kumpul merupakan upacara tradisional untuk mengiring pusaka Sunan Kumpul yang berupa Tombak Kyai Dora Manggala. Iringan-iringan dipimpin Camat Sawoo dan tokoh-tokoh pemerintahan kecamatan dan masyarakat. Sunan Kumpul tidak lain adalah Brojonatan yang dipercaya sebagai senopati dari Paku Buwono II Surakarta yang berjasa dalam kehidupan masyarakat Sawoo. Kirab pusaka ini menggunakan piranti/perlengkapan dan ceremonial yang mengandung nilai-nilai budaya, diantaranya; religius, gotong-royong atau kerjasama, rela berkorban, disiplin, saling hormat-menghormati, saling menghargai, patriotisme, patuh, bertanggung jawab, dan 
toleransi. Nilai-nilai tersebut memiliki potensi sebagai sumber pembelajaran IPS SMP kelas VII semester 1 yaitu pada KD 3.1 Memahami konsep ruang (lokasi, distribusi, potensi, iklim, bentuk muka bumi, geologis, flora dan fauna) dan interaksi antar ruang di Indonesia serta pengaruhnya terhadap kehidupan manusia dalam aspek ekonomi, sosial, budaya, dan pendidikan, materi pokok

Dinamika Kependudukan Indonesia.

\section{DAFTAR PUSTAKA}

Hanif M., (2016), Kesenian Dongkrek (Studi Nilai Budaya dan Potensinya Sebagai Sumber Pendidikan Karakter), Gulawentah: Jurnal Studi Sosial.2(2),132-141

Kementerian Pendidikan dan Kebudayaan. (2016). Peraturan Menteri Pendidikan dan Kebudayaan Republik Indonesia Nomor 24 Tahun 2016 Tentang Kompetensi Inti dan Kompetensi Dasar Kurikulum 2013 untuk SMP. Jakarta: Kementerian Pendidikan dan Kebudaya.

Komalasari (2010). Teori dan Teknik Konseling. Jakarta : Indeks

Miles, M.B., dan Huberman, A.M. (1992). Analisis Data Kualitatif. Jakarta: UI Press.

Musfiqon. (2016). Panduan Lengkap Metodologi Penelitian. Jakarta : Prestasi Pustaka.

Pemerintah Republik Indonesia. (2017). Undang-Undang Nomor 5 Tahun 2017 tentang Pemajuan Kebudayaan. Jakarta: Sekretariat Negara.

Rahyubi, H. (2012). Teori-Teori Belajar dan Aplikasi pembelajaran Motorik: Diskripsi dan Tinjauan Kritis. Bandung : Nusa Media.

Simanjuntak. (2016). Tradisi, Agama, dan Akseptasi Modernisasi pada Masyarakat Pedesaan Jawa. Jakarta. Yayasan Pustaka Obor Indonesia.

Suprayogo, I. (2001). Metodologi Penelitian Sosial-Agama. Bandung: Remaja RosdaKarya

Uhi. (2016). Filsafat Kebudayaan. Yogyakarta : Pustaka Pelajar

Winangun, W. (1990). Masyarakat Bebas Struktur, Liminalitas dan Komunitas. Yogyakarta: Kanisius

Wiyana, N.A. (2013). Desain Pembelajaran Pendidikan: Tata Rancang Pembelajaran menuju pencapaian Kompetensi. Yogyakarta : Ar-Ruzz Media. 